\title{
Remittances and Democratization
}

\author{
Abel Escribà-Folch, Covadonga Meseguer, and Joseph Wright \\ June 26, 2014
}

\begin{abstract}
Do remittances stabilize autocracies? Remittances, or money sent by foreign workers to individuals in their home country, differ from other sources of external non-tax revenue such as foreign aid because they accrue directly to individuals and thus raise the incomes of households. We argue that remittances increase the likelihood of democratic transition by undermining electoral support for autocratic incumbents in party-based regimes. Remittances therefore make voters less dependent on state transfers in autocracies. As a result, autocracies that rely heavily on the broad-based distribution of spoils for their survival, namely partybased regimes, should be especially vulnerable to increases in remittances. Evidence consistent with this argument suggests that remittances can promote democratization in some dictatorships.
\end{abstract}


Research on the economic consequences of immigration for receiving countries is immense and inconclusive. ${ }^{1}$ Some examine the political consequences of immigration in advanced countries, exploring, for example, the circumstances under which immigration leads to conflict (Dancygier 2010); the challenges to democracies of ascendant anti-immigrant groups (Messina 2007); and the risks of cultural backlash (Huntington 2004; Collier 2013). Furthermore, the economic impact of remittances, the transfer of funds associated with outmigration, has also been the subject of enormous attention from economists and policymakers (e.g. Kapur and McHale 2005, 2012; World Bank 2006). However, the other side of this phenomenon, the political consequences of out-migration for sending countries, remains largely understudied (Meseguer and Burgess 2014). Only recently have political scientists started to ask questions about how out-migration influences political change, and in particular democratization (Kapur 2010; Moses 2011; Pfutze 2012). Our paper addresses this second side of migration by examining the macropolitical consequences of remittance income for the survival of autocratic regimes, focusing on the prospects of democratic transition.

This paper shows that remittances can advance democracy in some autocratic contexts. We argue that worker remittances erode electoral support for autocratic incumbents in party-based regimes by undermining their capacity to mobilize and buy support through the delivery of goods and services to individuals. The democratizing effect of remittances should therefore be most consequential in regimes that rely primarily on the broad-based delivery of patronage and public goods to retain electoral support from a large coalition namely dominant party regimes.

The size of remittance flows and the fact that this income comes from outside the receiving country have led some scholars to compare remittances with other revenue windfalls such as foreign aid and oil. Numerous studies find that foreign aid and oil rents may make autocracies more resilient by providing rulers with non-tax revenues that reduce the need for taxation and that generate revenue that can be spent to buy political support or repress dissent. ${ }^{2}$ Some studies similarly suggest that remittances negatively influence democracy via the same mechanisms, such as patronage or rentierism, through which oil rents and aid harm democratic development. ${ }^{3}$ Recent research also argues that governments

\footnotetext{
${ }^{1}$ See, for example, the review by Orrenius and Zavodny (2012).

${ }^{2}$ On the negative effect of non-tax revenue, oil, and aid on democracy and authoritarian survival see, among many others Ross (2001); Smith (2004); Ulfelder (2007); Djankov, Montalvo and Reynal-Querol (2008); Smith (2008); Kono and Montinola (2009); Morrison (2009); Omgba (2009) and Bueno de Mesquita and Smith (2010).

${ }^{3}$ Recent research, however, has begun to question the empirical foundations of the political aid curse, finding that aid is associated with a higher likelihood of democratic transition during the post-Cold War period
} 
use remittances to divert resources that are then used to finance patronage. Consistent with this claim, Abdih et al. (2012) find that remittances lead to lower institutional quality and worsen corruption, while Ahmed (2012) finds that aid and remittances stabilize autocratic governments. $^{4}$

Yet remittances differ from aid and oil in ways which, we argue, make them distinct from other sources of foreign revenue. First, remittances are private transfers sent by individuals living and working abroad; migrants, not foreign governments or companies, are therefore the main source of remittances. Further, remittance transfers do not accrue to governments - like natural resource revenue or fungible aid - but directly to individuals, households, and organizations within a country. We build on the implications of these differences to explain how remittances influence political change in recipient countries.

We show that in some contexts remittances advance political development by fostering democratization. Worker remittances undermine the capacity of autocratic regimes to mobilize electoral support through the delivery of goods and services to voters. The democratizing effect of remittances should therefore be strongest in dominant party regimes that rely primarily on the broad based delivery of patronage and public goods to retain electoral support from a large coalition. Although other dictatorships also use patronage, we expect remittances to have a weaker influence on political change in these regimes because they generally have smaller support coalitions and thus rely less on the long-term transfer of state resources to large groups within society. Further, many non-party based regimes do not allow organized opposition parties to directly challenge the regime by competing for power in regular elections. Using data on up to 137 autocratic regimes from 1975-2009, we find that remittances increase the likelihood of a democratic transition in dominant party regimes. To explore the mechanism linking remittances to autocratic regime survival, we examine how remittances influence electoral behavior in autocracies, and find evidence that remittances are associated with lower electoral support for incumbent regimes.

\section{The Political Consequences of Remittances}

(Dunning 2004; Wright 2009; Bermeo 2011). Further, studies that account for country-specific factors question the empirical link between oil and democratization (Haber and Menaldo 2011; Wright, Frantz and Geddes 2014).

${ }^{4}$ However, Tyburski (2012) reports a negative association between remittances and corruption in Mexican states. 
Remittance flows to developing countries amounted to $\$ 325$ billion in 2010 and continue to grow, according to the World Bank. ${ }^{5}$ Foreign remittances have exceeded official aid flows and non-FDI private capital inflows to low- and middle-income countries since the late 1990s (Chami et al. 2008, 12). These patterns are also found in autocratic regimes. Further, remittance inflows are on average less volatile than other non-tax resources such as oil rents and foreign aid. ${ }^{6}$ Figure 1 shows that average oil income in autocracies remained steady through the 1990s and increased in the past decade as oil prices have risen. While remittances have also risen with oil prices in the 2000s, foreign aid to autocracies has not evidenced the same spike. The rise of remittances in the past two decades means that some countries' economies have become increasingly dependent on these flows. In countries as diverse as Albania, Lesotho, Haiti, and Jordan, remittances constitute more than 15 percent of GDP. Do these flows have political consequences for receiving countries?

\section{***Figure 1 about here***}

Figure 1: Foreign income in autocracies. Average per capita level of foreign income across all autocracies in Geddes, Wright and Frantz (2014). Figures depict the two-year moving average of constant US dollars. Aid and remittances data from World Bank (2010) and oil rents data from Ross (2008).

Relying on work by sociologists and anthropologists, political scientists are now exploring how patterns of transnational engagement influence political attitudes and behaviors in home countries as well as how emigrants exert "voice" after "exit" (Hirschman 1978; Goodman and Hiskey 2008; Iskander 2010; Careja and Emmenegger 2012; Meseguer and Burgess 2014). Abundant case studies show that emigrants engage in the politics of their home countries (Levitt 1998; Kapur 2010). Yet, we know little about the macro-political consequences of this transnational engagement for sending countries, as most studies focus on one country - mainly Mexico - or use individual-level data.

One group of studies uses survey data asking respondents about their migratory experience including receiving remittances - and political behavior. Other research examines how remittances affect electoral outcomes, such as voting for incumbent parties. Whereas the first set of papers finds that emigration has a demobilizing effect, the second shows that remittances generally reduce electoral support for incumbent parties and thus may further

\footnotetext{
5 This figure only includes transfers made through formal channels. See the World Bank's "Outlook for Remittance Flows 2011-2013."

${ }^{6}$ Since 1970, for example, the average standard deviation of remittances within autocratic countries is $\$ 15$ per capita. This figure is $\$ 25$ per capita for aid and over $\$ 500$ per capita for oil income.
} 
political change. Extant research therefore associates remittances with both decreased political mobilization and increased political change at the same time. In this section we review the mechanisms for these two opposing effects and then, in the next section, discuss how these mechanisms influence the prospects of democratization in different autocratic contexts.

Using a variety of surveys based on Mexican respondents, Pérez-Armendáriz and Crow (2010), Goodman and Hiskey (2008), and Germano (2013) find that emigration experience reduces certain types of political behavior, such as voting, talking about politics, punishing incumbent parties in elections, and seeking political information. Two mechanisms may explain these findings. First, Goodman and Hiskey $(2008,170)$ posit that having relatives abroad and receiving remittances reorient individuals toward transnational political activities as they rely more on families and less on the state to satisfy their needs. Second, and more importantly, remittances may insulate recipient households from domestic economic conditions and thus reduce economic grievances. Remittances usually accrue to households in countercyclical patterns, which helps to smooth domestic economic shocks and consumption volatility. This might reduce dissatisfaction with the incumbent regime and preclude political change, perhaps by lowering the risk of civil war (Regan and Frank 2014).

In contrast, other studies contend that remittances foster political change, and even democratization, via three main mechanisms: an income effect, contentious mobilization, and social learning. First, remittances increase recipient households' income, which in turn augments resources necessary for political participation, such as time and money. One version of this argument posits that additional non-labor income in the form of remittances makes individuals less dependent on the state's clientelistic spending, prompting individuals to reduce their electoral support for incumbent parties or to engage in other forms of participation such as protests. For example, using municipal election data in Mexico, Pfutze (2012; 2013) tests the social learning and the income mechanism but only finds support for the latter: remittances reduce turnout for the ruling Partido Revolucionario Institucional (PRI) in municipalities where the PRI was entrenched. Similarly, Díaz-Cayeros, Magaloni and Weingast (2003) show that a higher percentage of a municipal population living in the U.S. a proxy for remittances - is associated with a higher likelihood that a municipality defects from the PRI and votes for the opposition. 
Second, remittances may be used to support particular candidates and parties in receiving countries or to finance protest activities back home. ${ }^{7}$ Remittances can thus influence domestic politics in sending countries when they are used to directly fund opposition political groups. Migrant diasporas, for example, can be a key source of financing for domestic rebel groups, which may increase the feasibility of an armed uprising and, as a result, raise the likelihood of civil conflict (Collier and Hoeffler 2004). Using survey data from sub-Saharan Africa, Dionne, Inman and Montinola (2014) show that individuals who report receiving remittances are more likely to participate in protests but less likely to vote than those who receive no remittances. In more institutionalized polities, remittances can finance legal opposition parties and thus increase their capacity to challenge the incumbents in elections. ${ }^{8}$ Others find that emigrant remittances can increase the resources available for collective challenges to the state, increasing the risk of civil war (Miller and Ritter 2014).

Third, remittances may involve the transfer of "social remittances", which consist of the flow of new ideas, values, and behaviors from migrants to their sending countries (Levitt 1998). The transfer of social remittances occurs through long-distance cross-border interactions, face-to-face cross-border interactions, and migration information networks (Levitt 1998; Pérez-Armendáriz and Crow 2010; Pérez-Armendáriz 2014). Thus, contact with emigrant relatives may increase participation and dissent through a process of social learning via the spillover of civic and democratic values, which can alter the distribution of political preferences and behaviors in sending communities (Pfutze 2012, 2013; Pérez-Armendáriz 2014). For example, Pérez-Armendáriz and Crow (2010) find that knowing migrants whether friends or relatives - increases levels of political participation and dissatisfaction with incumbents in Mexico.

Most research to date focuses on how remittances influence politics in new democracies and specifically Mexico (Goodman and Hiskey 2008; Pérez-Armendáriz and Crow 2010; Pérez-Armendáriz 2014; Pfutze 2013; Germano 2013; Tyburski 2012). ${ }^{9}$ However, research on the political influence of remittances need not be restricted to democratic settings (Díaz-Cayeros, Magaloni and Weingast 2003; Pfutze 2012). The only paper that examines remittances and macro-political change using a broad sample of

\footnotetext{
${ }^{7}$ See Burgess (2014) for a study of the determinants of migrants' political engagement in their home countries' politics.

${ }^{8}$ Indeed, recent cross-national research demonstrates that emigrants send more money home at election time in developing countries, especially during multiparty contests (O'Mahony 2013;Nyblade and O'Mahony 2014). However, these studies do not clarify whether the funds go to finance the incumbents, the legal opposition, or other types of groups.

${ }^{9}$ See Meseguer and Burgess (2014) for a review.
} 
autocracies is Ahmed (2012), which examines two types of foreign income together: aid and remittances. ${ }^{10}$ This study posits that autocracies use aid to finance patronage (an income effect); and that as remittances increase private consumption, governments divert expenditures from the provision of welfare to private spending (a substitution effect). Both mechanisms result in extra resources for regimes to fund patronage. However, as noted above, inflows of aid - if fungible - accrue directly to the state while individual remittances accrue largely to households. Hence, these two income flows may have distinct (even opposite) effects on democratization. Moreover, by focusing on how autocracies differ from democracies this research ignores the question of how regimes in different autocratic contexts benefit from or are harmed by remittance flows. The next section discusses the proposed mechanisms linking remittances to the prospects of democratic change in different autocratic regimes and advances a theory to explain why remittances further democracy in party-based dictatorships.

\section{Remittances and Autocratic Regime Survival}

Are some regimes more vulnerable to workers' remittances? Autocratic regimes differ along many dimensions, such as the size of their support coalition (Bueno de Mesquita et al. 2003), the group from which elite supporters are selected (Geddes 1999), and the extent to which they coopt potential opponents with policy concessions (Gandhi 2008). These characteristics influence a regime's durability and its vulnerability to domestic and foreign shocks. We argue that foreign remittances destabilize autocracies by reducing citizens' dependence on government transfers and public goods. By giving individuals and households an exit option from the regime's patronage network, remittances sever the clientelistic link between voters and incumbent dictators causing defections from their support coalition. Further, by increasing the resources of opposition parties and groups, remittances may increase the capacity of these parties to challenge the regime in autocratic elections.

These mechanisms, we argue, are more likely to occur in dictatorships that hold multiparty elections regularly and rely primarily on broad-based distribution of goods to purchase the loyalty of large coalitions and deter investment in the opposition. Concretely, remittances should undermine the capacity of dominant party regimes to mobilize political support by reducing voters' dependency on state-delivered goods.

\footnotetext{
${ }^{10}$ See Bearce and Hutnick (2011) for a discussion of the impact of immigration on democratization.
} 
Dominant party regimes are dictatorships in which "a party organization exercises some power over the leader at least part of the time, controls the career paths of officials, organizes the distribution of benefits to supporters, and mobilizes citizens to vote and show support for party leaders in other ways" (Geddes 1999, 124). The latter two features help us understand how remittances may weaken these regimes. Dominant party dictatorships tend to have broader and deeper support coalitions than other regimes; and their survival therefore depends not only on institutionalized power-sharing agreements and the provision of private goods to top party officials and other elites (patronage), but also on the delivery of (often local) public goods to larger segments of the population (clientelism) aimed at mobilizing mass support (Bueno de Mesquita et al. 2003; Magaloni and Kricheli 2010; Malesky, Abrami and Zheng 2011). Thus, parties not only serve to channel elites' demands and credibly share power with significant groups, but also work as large clientelistic machines through which benefits are distributed in an effort to mobilize supporters (Magaloni 2006; Greene 2007; 2010; Pepinsky 2007; Levitsky and Way 2010). ${ }^{11}$ The capacity to organize the distribution of benefits to supporters is made possible by the party's ability to politicize public resources which can then be transformed into patronage goods (Greene 2010, 808). This usually results in party regimes having large public sectors (Desai, Olofsgard and Yousef 2009; Greene 2010).

The party monopoly over state resources makes it possible for the regime to control access to public housing, social services, property, fertilizers, subsidies, scholarships, jobs, and even food. And, most importantly, it allows the incumbent to make this access conditional on support for the regime party. This ensures that important segments of society are economically dependent on the regime (Magaloni and Kricheli 2010). Benefits to citizens can take the form of private goods. For example, public housing programs enacted by the ruling People's Action Party (PAP) in Singapore have been a key source of support and votes for the regime since 1960. During elections in Malaysia, workers from the ruling party, the United Malays National Organization (UMNO), visit rural households to dispense cash payments to supporters and deter opponent mobilization (Pepinsky 2007, 144). But most commonly, the benefits delivered from dominant parties take the form of targeted public goods and services. In Malaysia, federal politicians distributed grants for rural development to local clients to reward support for UMNO (Pepinsky 2007). Blaydes $(2011,74)$ shows that during Mubarak's rule in Egypt, areas that voted for the opposition saw little improvement in

\footnotetext{
${ }^{11}$ As Magaloni and Kricheli $(2010,124)$ and Levitsky and Way $(2010,62)$ note, both functions are interwoven: mobilization of mass support is essential to deter defections from within the elite.
} 
sewerage and water coverage between the mid 1980s and 1990s. Under PRI rule in Mexico, PRONASOL funds, mainly consisting of public works targeting municipalities, were systematically directed to ensure voters' loyalty in contested municipalities and withdrawn from those supporting the opposition (Magaloni 2006).

Individuals receive targeted benefits and public goods and services in exchange for supporting the regime. This support can take the form of tacit acquiescence or party membership, but it most often involves endorsing the ruling party in elections. Elections are not uncommon in dictatorships; indeed a majority of dictatorships held multiparty elections in the past decade (Hyde and Marinov 2012; Gandhi and Lust-Okar 2009). Almost all dominant party regimes hold regular national elections, and these regimes hold elections more frequently than other types of autocracies (Geddes 2003). Autocrats use elections to deal with different kinds of threats and intend to win them (Gandhi and Lust-Okar 2009). Consequently, among other strategies such as voter intimidation and restrictions on opposition parties, party regimes exploit their resource advantage to fund clientelistic practices - where ruling parties exchange votes for material benefits and services - and to enjoy a privileged economic and media position during electoral campaigns (Dixit and Londegran 1996; Magaloni 2006; Greene 2010).

The previous section identified three mechanisms through which remittances may foster political change: severing clientelistic links between citizens and the ruling party; increasing funding for opposition parties and groups; and social remittances, or the spillover of civic and democratic values. Our hypothesis suggests that remittances should undermine autocratic survival in dominant party regimes principally through the income effect of remittances, and possibly through an increase in resources available to opposition parties. We argue that remittances weaken party regimes by reducing citizens' dependence on clientelistic transfers, and thus increase their economic autonomy, namely their "ability to earn a living independent of the state" (McMann 2006, 28). By increasing private income, remittances reduce the marginal utility of state-provided targeted benefits as well as local public goods and services.

This argument builds on the stylized fact that remittances increase household consumption to acquire goods and thus represent a substitute for goods provided by the regime. Existing research shows that recipient households use remittance income to finance private consumption but also investments in education, health, agriculture, and business (World Bank 2006a, 2006b; Fajnzylber and López 2007; Chami et al. 2008). Additionally, remittances enable citizens to obtain local public goods that substitute for government 
welfare and infrastructure expenditures. For example, Adida and Girod (2011) find that Mexican households use remittances to purchase access to public services, such as sanitation and clean water, undermining the state monopoly on the provision of these goods. In Yemen, during the 1970s, local cooperatives used remittances to invest in road construction, schools, clinics, and farming projects (Chaudhry 1989, 133-134). In Senegal, migrant associations (dahiras) use remittances to fund projects and social services in their communities of origin "without having to rely on state intervention" (Diedhiou 2011, 6). These examples suggest that remittances provide households and individuals with an 'exit' from the regime's clientelistic network (Díaz-Cayeros, Magaloni and Weingast 2003; Ahmed 2011; Pfutze 2012).

Two requisite conditions underpin the logic of the income effect: (1) remittance recipients care about ideological preferences; and (2) the regime cannot substantially expand its budget by extracting revenue from remittances, which can then be used to buy political support from remittance households. The first condition is a standard assumption in models of clientelism, where voter utility is a positive function of income and a negative function of support for the regime/incumbent party as captured by the distance between their own ideological position and that of the party they support. Hence, clientelistic transfers decrease (to zero at the limit) as an individual's support for the regime increases or is ideologically closer to the incumbent party. Transfers, in these models, are the price the regime pays to alter the individuals' political behavior. ${ }^{12}$ As Magaloni and Kricheli $(2010,128)$ argue, "[c]itizens with alternative sources of income can better afford to make ideological investments' in democratization and oppose the regime." Likewise, McMann (2006) posits that 'economic autonomy' can explain citizens' willingness to challenge local authorities instead of self-censoring their preferences. Further, poorer voters are more easily trapped by clientelistic networks, as lower incomes reduce the price the regime must pay in exchange for support. Substantial evidence suggests that remittances benefit the poor and help reduce poverty. ${ }^{13}$ By increasing income and thus the monetary value of transfers needed to buy

\footnotetext{
${ }^{12}$ See, for example, Pfutze (2013) for a formalization of this argument.

${ }^{13}$ Fajnzylber and López (2007) show that Mexican remittance recipients are predominantly poor, with 61 percent of the households that report receiving remittances falling in the first quintile of non-remittances income, whereas only 4 percent of them are in the top quintile. Further, this report states that "once we take into account remittances income, recipient households significantly climb the income ladder. In fact, after we take into account the role of remittances, only 10 percent of the households that receive them belong to the lowest quintile of the income distribution. In contrast, on the basis of total income, more than 30 percent of the households receiving remittances would now be in the highest income quintile. Thus, this aggregate analysis indicates that remittances seem to have a positive impact on the incomes of the poor" (Fajnzylber and López
} 
support, remittances weaken state clientelism, lowering the marginal utility of such transfers and increasing the importance of ideological preferences in voting and other political decisions.

The second condition is that the regime cannot substantially augment its resources by capturing remittances, which can then be used to offset the increase in the price of continued support. Numerous studies agree that remittances are largely non-taxable (Chaudhry 1989; Abdih et al. 2012; Pfutze 2012; 2013; Ahmed 2012). The World Bank (2006b, 93), for example, notes that "[m]ost remittance-receiving countries today do not impose taxes on incoming remittances." In practice, remittances are rarely directly taxed because they are highly elastic to the tax rate as remitters can easily evade formal controls (Eckstein 2010). Thus, directly taxing remittances is likely to result in fewer remittances sent through formal channels (Freund and Spatafora 2008). For this reason, we follow the extant research in suggesting that remittances are generally not taxable and do not substantially increase nondemocratic governments' revenues. ${ }^{14}$

Empirical tests of this argument in Mexico show that remittances decrease votes cast for the incumbent and benefit the opposition by weakening of clientelistic ties (Pfutze 2012; 2013). Dahou and Foucher $(2009,17)$ concur, noting that "[ $t]$ he shift of the Senegalese economy from groundnuts to migration and its increasing dependence on resources generated abroad could be seen as the final stage in the process of ending the hegemony once enjoyed by the state over Senegalese society." Senegal transitioned to democracy in 2000 when the incumbent Socialist Party lost the presidential election. However, we lack systematic tests of this argument for a large number of autocracies.

Thus, we expect remittances to increase the likelihood of democratic transition. We should find the strongest support for this expectation in dominant party dictatorships as opposed to other autocracies because the former typically: (1) have organized opportunities for collective action and the expression of dissent, particularly via elections (Geddes 2003); and (2) have broader and deeper support coalitions comprising poor households in which we expect the income effect of remittances to operate most strongly. To explore the proposed mechanism linking remittances to democratization, we further examine whether remittances alter electoral behavior in autocracies in a way that punishes the incumbent.

2007, 33). Adams and Page (2005) also show that remittances reduce the level and severity of poverty in developing countries, while other cross-country studies provide similar evidence (IMF 2005; Ratha et al. 2011).

${ }^{14}$ Our analysis in Appendix E using a sample of autocracies finds no evidence that remittances increase tax revenue. 
First, weakening clientelism permits individuals to revise their evaluation of the government and express their true preferences about the regime. When the utility of registering disapproval of the regime - given remittances - is larger than that of supporting it, expressing dissent can not be too costly. Dominant party regimes are both less repressive (Davenport 2007) and more likely to have regular, institutionalized mechanisms for leadership turnover that typically occur through elections (Geddes 2003). If the ruling party loses an election, this generally leads to a democratic transition. In other regimes, in contrast, destabilizing dissent is more likely to take the form of contentious collective action (Ulfelder 2005).

Second, dominant party regimes have broader winning coalitions than other autocracies and politicize public resources to mobilize support. To retain power, the regime party typically wins elections. Broader support coalitions in these dictatorships are more likely to contain poorer households that rely on remittances. In many countries, the share of households that receive remittances is substantial. ${ }^{15}$ Further, the positive income effect of remittances may not be limited to direct recipients, as foreign income can have multiplier effects leading to improvements in the living conditions of non-migrant households as well (World Bank 2006b). These spillover effects should increase "environmental economic autonomy" (McMann 2006). Through the income mechanism, remittances should undermine clientelistic ties and make some individuals and localities more likely to manifest disapproval or withdraw their support for the regime party. Elections can reflect the loss of political support from the coalition, as a decline in turnout for the incumbent party may lead to electoral victory for opposition parties, as occurred in Mexico and Senegal in 2000.

Other dictatorships - particularly personalist regimes - also rely on the distribution of benefits to supporters, but they are more likely to have a relatively small coalition comprised mainly of individuals with family and ethnic ties to the leader (Geddes 2003). In contrast, party regimes more often coopt large groups of potential opponents into the support coalition or rely on large preexisting organizations such as labor unions or independence movements

\footnotetext{
${ }^{15}$ Data for some relevant cases in our sample suggest as much. More than 25 percent of Haiti's households received remittances in 2001 (Fajnzylber and López 2007). Survey data from 2004 in Mexico indicate 21 percent of Mexicans received remittances (González et al. 2011, 99-100). More than 60 percent of those interviewed affirmed having a relative living in the U.S., and one third reported that remittances represent half or more of total household income. In Senegal, recent data suggests that 32 percent of households receive remittances regularly (Orozco, Burgess and Massardier 2010). According to a recent Gallup survey, by 2009-10 the percentage of households receiving remittances in Mexico was 7 percent; 17 percent in Paraguay; 7 percent in Serbia; 22 percent in Senegal; 8 percent in Kenya; 9 percent in Sri Lanka; 22 percent in Niger; and roughly 5 percent in Indonesia (http://bit.ly/k5plfa [accessed 28 July 2013]). Finally, official remittance figures may underestimate the true number due to the extensive use of informal channels of sending remittances (World Bank 2006b).
} 
(Bratton and van de Walle 1994; Geddes 1999; Smith 2005). In personalist dictatorships, which typically have smaller support coalitions than party dictatorships, this group is less likely to contain poorer individuals whose main income comes from remittances. The political support of relatively lower income supporters is therefore less likely to be necessary to retain power in non-party based regimes. Further, benefits accruing to each member of a personalist coalition are private goods and thus substantially larger (Bueno de Mesquita et al. 2003). It is therefore less likely that utility from remittances exceeds the benefits obtained by supporting the regime. Thus, even though patronage politics is central to the logic of personalist rule, we do not expect remittances to undermine the patronage links between regime supporters and the dictator in personalist regimes. ${ }^{16}$ In military regimes, patronage may be present too but it is not the main instrument such regimes use to retain power. Rather, repression and institutional power-sharing between branches or factions within the military are (Davenport 2007; Geddes, Frantz and Wright 2014).

There may be other mechanisms through which remittances enhance the prospects of democratization, particularly in dominant party regimes. However, these mechanisms are likely to strengthen our argument. For example, migrant diasporas can directly influence political events in sending countries by disseminating information, framing political issues, financing candidates and parties, and lobbying foreign governments and international organizations. As O’Mahony $(2013,805)$ notes, “[p]olitical contributions may be given directly to parties by migrants or passed on to politicians by migrants' families." Thus, remittances may work in conjunction with migrant diasporas that help finance and mobilize domestic opposition groups.

The influence of augmented political resources for opposition mobilization should differ across autocratic contexts as well. Regular elections in dominant party regimes often pit legal opposition parties against the incumbent. The ruling party wins these elections because it enjoys resource advantages thanks to its monopoly access to public resources and statecontrolled institutions such as the media (Magaloni 2006; Greene 2010). Excluded from such resources, opposition parties can greatly benefit from foreign contributions, increasing their ability to compete for office, thus facilitating democratic transition. Hence, in dominant party regimes remittances may undermine the resource advantage ruling parties enjoy by providing opposition groups with funds they are unable to generate domestically.

\footnotetext{
${ }^{16}$ We confirm these expectations about the influence of remittances in personalist dictatorships in Appendix Table A-5.
} 
For example, in Ethiopia opposition parties that had boycotted the 1995 and 2000 elections won 172 seats in the 2005 parliamentary election, while the ruling EPRDF retained "only" 327 seats - more than 150 fewer seats than it had won in the 2000 election. As Lyons (2007, 540) emphasizes, "[t]he two main opposition coalitions that participated in the May 2005 elections had clear roots in the diasporas of North America and Europe." In fact, most of the campaign funding for one of the main opposition coalition groups, the Coalition for Unity and Democracy, came from diaspora communities (Arriola 2008, 120).

In contrast, in regimes that are less likely to have regular and competitive mechanisms for leadership succession, remittances may simply increase the capacity of outside groups to forcibly oust the regime. In autocratic contexts where opposition groups and parties are banned, diaspora funds may finance insurgencies (Collier and Hoeffler 2004). ${ }^{17}$ While remittances in these cases may increase the prospects of a forced, or even violent, regime change, these regime ousters usually lead to a subsequent autocracy and not to democracy (Geddes, Wright and Frantz 2014).

Finally, emigration can also foster social learning by transmitting ideas and information about social norms, including democratic values, to those left behind (Levitt 1998; Pérez-Armendáriz 2014). However, the social learning mechanism would operate provided emigrants settle in advanced, well governed democracies, which is far from the rule in many developing countries (World Bank 2011). Further, emigration - rather than economic remittances - should be a better measure of transferring values because outmigration is more likely to reflect political preferences as citizens leave when they dislike the state of political affairs at home (Hiskey, Montalvo and Orcés 2014). Thus, their departure may decrease turnout for the incumbent (Pfutze 2013). Addressing the multiple mechanisms through which emigration may influence democratization requires time-series data on emigration, but existing data is low quality, with poor coverage for most autocratic countries. ${ }^{18}$ Yet, we acknowledge that emigration can be a potentially confounding variable and show that the influence of remittances is robust to controlling for net migration, which is the best available measure given our research design.

\footnotetext{
${ }^{17}$ Available data on formal remittances is less likely to capture the informal funds accruing to outside groups from diasporas (Regan and Frank 2014). In Appendix Table A-6, we test whether formal remittances are associated with an increased likelihood of autocratic transition; as expected, we find no significant effect. To account for the fact that remittances may facilitate political protests, we control for the occurrence of protest events in some specifications.

${ }^{18}$ Only a few published studies account for emigration empirically (Goodman and Hiskey 2008; Pfutze 2013). This research relies on a cross section of municipalities, which allows the authors to use census data. We cannot follow the same strategy with times-series cross-country data.
} 


\section{Data and Methods}

Whereas prior research explores how remittances influence government change, our focus is democratic transition. ${ }^{19}$ These regime transitions occur when the ruling elite lose power and the new government that replaces the fallen regime is democratic. When some autocratic regimes fall, they are replaced by a new autocracy, as was the case during the 1979 Iranian Revolution when a theocratic regime overthrew the Pahlavi dynasty. We do not examine these types of autocratic regime failures because they rarely come about via an election, which is the proposed mechanism through which we expect remittances to influence autocratic stability. More importantly, the measure of democratic transition excludes government changes that occur during the lifetime of an autocratic regime. "Government change" in many autocracies occurs when one leader replaces another via an institutionalized mechanism for rotating the leadership of the regime. When these events do not coincide with regime failure, they are often successful maneuvers by incumbent elites to prolong their rule and should not be interpreted as political instability. Examples from regimes in Mexico and Saudi Arabia illustrate.

In Mexico, the long dominant PRI lost its monopoly on power when an opposition candidate won the Presidency in 2000. During much of its nearly eight decades of rule, the PRI selected a new leader every six years. These leadership changes may constitute "government change" ${ }^{20}$ but they are not a reliable measure of autocratic instability because they conflate the leader and the regime in an autocracy where selection of new leaders is a regime feature that enhances its chances of survival (Magaloni 2006).

Similarly, the natural death of a leader may not threaten the regime with collapse, even though naming a new leader can constitute "government change." Monarchies, for example, often have established mechanisms for leadership succession within the royal family. Because these regimes have dynastic political structures that institutionalize the selection of new leaders without jeopardizing the regime itself, they are relatively resilient (Herb 1999, 40-49; Menaldo 2012, 711). In Saudi Arabia, the monarchy continues in power

\footnotetext{
${ }^{19}$ Ahmed (2012), for example, uses the variable "years in office" from the Database of Political Institutions (DPI) which marks how long the leader or ruling party has been in power.

${ }^{20}$ Government change in Mexico, according to the DPI, occurred in 1976, 1982, 1994, and 2000 but not in 1988. Notably, the PRI split prior to the 1988 election, when Cárdenas formed the opposition Party of the Democratic Revolution (PRD), and the PRI used electoral fraud to win. Thus, according to this measure, instability in Mexico occurred every six years except during the year it faced its strongest electoral challenge prior to 2000 .
} 
despite "government changes" that occurred after King Khalid died of a heart attack in 1982 and after King Fahd succumbed to pneumonia in 2005. ${ }^{21}$ The data-generating process we model excludes natural deaths of the leader when the regime remains in power, as we do not expect remittances to influence these events.

To test the main hypothesis, we use data from Geddes, Wright and Frantz (2014), which codes two types of regime collapse: those that lead to a transition to democracy and those that result in a new autocratic regime. ${ }^{22} \mathrm{We}$ focus on democratic transitions and treat transitions to a new dictatorship as right-censored. The dependent variable is coded 1 if a regime change that results in democracy takes place in a given year and 0 otherwise. Democratic transitions are relatively rare, occurring in 3 percent of observation years.

The main explanatory variable is worker remittances, from the World Development Indicators (2010), measured in constant U.S. dollars per capita (logged). To avoid reverse causality, we lag this variable one year. We use this measure instead of remittances as a share of GDP because the latter is composed of two variables - remittances and GDP - making it difficult to disentangle which one influences transitions. For instance, sustained growth increases GDP, which entails a lower value of $\frac{\text { Remit }}{G D P}$. If sustained growth - and hence lower values of $\frac{\text { Remit }}{G D P}-$ influences stability in autocracies, we might observe a spurious correlation between $\frac{\text { Remit }}{G D P}$ and transitions, driven by changes in the denominator (GDP) rather than the numerator (remittances).

The other main explanatory variable is party regime, which is a binary indicator from Geddes, Wright and Frantz (2014). Of the 137 regimes in the sample 39, or 29 percent, are party regimes. ${ }^{23}$ However party regimes comprise 41 percent of the sample observations because they tend to endure longer than many other autocracies. This variable measures concepts related to the electoral basis of regime support, such as: whether the regime has a support party with local level organizations; whether the party holds competitive intraparty elections; and whether party supporters include members of more than one regional, religious, or ethnic group (Geddes 2003). In contrast, other autocracies are categorized as military, monarchical, or personalist. While military regimes and monarchies have other organizational mechanisms for securing support and managing elite conflict (i.e. the military

\footnotetext{
${ }^{21}$ Even the assassination of King Faisal in 1975 "did not reflect any wider split within the royal family and did not disturb the equilibrium of the institution" (Herb 1999, 99).

${ }^{22}$ As a robustness test, we replicate the main finding using the Cheibub, Gandhi and Vreeland (2010) coding of democratic transition (Table A-3).

${ }^{23}$ For the reported results we group party-hybrid regimes with pure dominant party regimes. The main results hold for both pure and hybrid-party regimes (Table A-5).
} 
and the royal family), personalist dictatorships: tend to lack a broad-based support party; have leaders who create their own party rather than inherit a support party from their predecessor; are less likely to govern with routine elections; and if they have elections these are more likely to resemble plebiscites than competitive contests.

To test the main hypothesis, we interact the two main variables: Remit $\times$ Party. We test this model as well as specifications that include controls for: log GDP per capita; log Population; neighboring country democratization; and civil war - all lagged one year. ${ }^{24}$ Then we add a control variable for net migration, which helps isolate the influence of remittances while accounting for the net loss of citizens. ${ }^{25}$ Next, we test a specification with controls for growth and anti-government protest. $^{26}$ These represent alternative channels through which emigration might influence autocratic stability, independently of remittances. For example, remittances are often counter-cyclical income flows correlated with economic growth, which may independently influence regime survival. Last, we test a specification that controls for other channels of foreign influence: foreign aid, oil rents, and capital account openness. The aid and oil variables are each logged, lagged two-year moving averages, while capital account openness is an index that measures the extent of capital controls based on the information from the IMF's Annual Report on Exchange Arrangements and Exchange Restrictions. ${ }^{27} \mathrm{We}$ account for duration time dependence by including polynomials of regime duration (Carter and Signorino 2010). ${ }^{28}$ To model global shocks to democratization as well as the global trend in remittances, we include a quadratic calendar time trend.

Finally, we address unit heterogeneity by conditioning the explanatory variables on their respective unit means $\left(\bar{X}_{i}\right)$. This approach is similar to directly modeling country fixed effects. However, we opt for the unit means approach because directly including country fixed effects forces a binary dependent variable model to drop highly stable autocratic

\footnotetext{
${ }^{24}$ GDP per capita and population data are from the World Development Indicators (WDI 2010). Neighboring country democratization takes three values: 0 for no neighboring country democratic transitions; 1 for one transition; and 2 for 2 or more, where neighbor is defined as any autocratic country with a capital city within $4000 \mathrm{~km}$ of the target country. Civil war, from Gleditsch et al.(2002), takes 3 values: 0 for no civil war; 1 for at least one low intensity civil war; and 2 for at least one high intensity civil war.

${ }^{25}$ Net migration data is from World Bank (2010), measured every five years. We use this measure for each of the five years following the year in which this variable is reported.

${ }^{26}$ Economic growth, measured as the 2-year lagged moving average, is from World Bank (2010). Protest data is the lagged, logged value of the number of riots, strikes, and anti-government demonstrations, from the Banks data set.

${ }^{27}$ Foreign aid data is constant dollars per capita from World Bank (2010); constant dollar oil and gas rents per capita from Ross (2008); and the capital account openness index is from Chinn and Ito (2008).

${ }_{28}$ Beck, Katz and Tucker (1998) show that a binary dependent variable model, such as a logit, is a similar estimator to standard duration models if we include controls for time dependence.
} 
countries that do not democratize during the sample period. ${ }^{29}$ For example, a conditional logit drops stable regimes such as the monarchy in Jordan and dominant-party regimes in Botswana and China. Our approach attempts to circumvent this issue by conditioning on the unit means of the explanatory variables as a substitute for country fixed effects (Wooldridge 2002, 487). In doing so, the interpretation of the explanatory variables is similar to the interpretation from a fixed effects model. To address any further unit heterogeneity not captured by the fixed effect proxy $\left(\bar{X}_{i}\right)$, we estimate the equation with random effects and clustered standard errors. ${ }^{30}$ The specification is:

$$
\operatorname{Pr}\left(Y_{t}=1 \mid Y_{t-1}=0\right)=\alpha_{j[i]}+\beta X_{i, t-1}+\gamma \bar{X}_{i}+\varepsilon_{i, t} ; \quad \alpha_{j} \sim N\left(\mu_{\alpha}, \sigma_{\alpha}^{2}\right) ; \quad \varepsilon_{i, t} \sim N\left(0, \sigma_{y}^{2}\right)
$$

where $X$ includes the explanatory variables, regime duration polynomials, and a time trend. After we present the results from this model, we examine a two-stage model that uses an instrument to capture exogenous variation in remittances.

\section{Results}

Table 1 presents results for testing whether remittances increase the likelihood of democratic transition. The odd-numbered columns report models with no interaction while the evennumbered columns report results that include Remit $\times$ Party. The first two columns report models that include controls for party regime, duration dependence polynomials, and a quadratic calendar time trend. The next two include four additional variables: GDP per capita, Population, Civil war, and Neighbor democratization. The next two add Net migration; columns 7 and 8 add Economic growth and Protest; and the final two models add Foreign aid, Oil rents, and Capital account openness as control variables. All models include the unit means as explanatory variables.

$$
\text { *** Table } 1 \text { about here } * * *
$$

The results for remittances in party regimes are consistent: a large, positive and statistically significant coefficient for the interaction term as well as for the linear

\footnotetext{
${ }^{29}$ Appendix Table A-2, columns 5 and 6 show that the main result remains when using a conditional logit, even though this approach drops 49 of 88 countries. Further, we test a linear probability model with country- and year-fixed effects, reported in columns 3 and 4 in Table A-2, again with results similar to those reported in Table 1.

${ }^{30}$ By construction, the estimates of the main variables (i.e. not the unit means) are the same irrespective of whether we center these variables around the mean.
} 
combination, $\beta_{\text {Remit }}+\beta_{\text {Remit } \times \text { Party }}$, which estimates the marginal effect of remittances in party regimes. This indicates that remittances in party regimes are correlated with the likelihood of democratic transition. Figure 2 shows the substantive result from the model in column 4 . It depicts the simulated predicted risk of democratic transition across a range of values for remittances. ${ }^{31}$ In party regimes, increasing remittances by two standard deviations around the mean raises the simulated predicted risk of transition from 0.1 percent to 2.4 percent. In other dictatorships, this increase in remittances changes the predicted risk of transition from 1.2 percent to 1.5 percent.

To test the robustness of this finding, Appendix Tables A-1 to A-3 report models that control for: (1) state capacity; (2) repression; (3) protest interacted with remittances; (4) using a remittance variable without population in the denominator; (5) using the lagged two-year moving average for remittances; (6) including the year means of the explanatory variables instead of a time trend; (7) employing a linear probability model with country- and year-fixed effects; ${ }^{32}$ (8) with a conditional logit; (9) dropping Latin American countries from the sample; and (10) using a different measure of democratic transition from Cheibub, Gandhi and Vreeland (2010). Further, Figure A-1 shows the result is robust to the exclusion of any country with a party-based regime.

$$
\text { ***Figure } 2 \text { about here*** }
$$

Figure 2: Remittances and democratization. The figure depicts the simulated predicted probability of a democratic transition. The dotted line depicts the predicted risk of democratization in non-party based regimes, the dashed line depicts democratic transition risk for party regimes. Horizontal axis represents a range of values for remittances, with the shaded histogram depicting the distribution of remittances $(\log )$ in the sample, up to the 95th percentile.

\section{Two-stage model}

To address the concern that remittances are endogenously determined by political change in the receiving country, we use an instrument that combines information from: the time trend for received remittances in high-income OECD countries as well as the share of a country's land that lies within $100 \mathrm{~km}$ of a coastline and the share of land area that contains fertile soil. First we sum remittance receipts in high-income OECD countries (per capita constant dollars)

\footnotetext{
${ }^{31}$ The simulation sets the value of all explanatory variables (including the unit means) at their respective withinsample mean, except for the calendar time trend which is set at 1993 and regime duration which is set at the median.

${ }^{32}$ Figure A-2 shows the result from linear probability models with country- and year-fixed effects.
} 
in each year World Remit $_{i, t}=\sum_{j}$ Remit $_{j, t}$, where $j$ are high-income OECD countries, none of which are autocracies. Remittances received by citizens in high-income OECD countries mostly come from other rich OECD countries. The World Bank, for example, estimates that 83 percent of emigrants from high-income OECD countries migrate to other high-income OECD nations (World Bank 2011, 12). Thus domestic factors in OECD countries, such as economic growth and level of development, which influence remittance receipts from other high-income OECD countries also determine the extent to which migrants from autocratic countries who work in these rich OECD countries send remittances back home. Thus we find that the yearly average of high-income OECD remittances is correlated with remittances sent to non-OECD autocratic countries. Remittances received in high-income OECD countries are unlikely to directly influence political change in remittance-receiving autocratic countries except through their indirect effect on remittances sent to autocratic countries. We control for the possibility that remittances received in OECD countries reflect global economic trends that also influence domestic politics in autocratic countries by adding calendar time trends. ${ }^{33}$

Information on the high-income OECD trend in remittances received varies by year. To add cross-sectional information, we weight the trend by the share of land area in the receiving autocratic country that lies within $100 \mathrm{~km}$ of a coast line multiplied by the share of land area with fertile soil. ${ }^{34}$ We call this variable W RemitDistance. This strategy is similar to Abdih et al. (2012), who use the ratio of coastal area in a recipient country to total area as a cross-sectional instrument. Coastal land area is correlated with ease of emigration and therefore emigrant population and remittances received, while fertile soil is correlated with population density. But neither of these geographic features is endogenously determined by domestic political outcomes. Other ways through which coastal land and fertile soil might influence politics are captured in GDP per capita, economic growth, and civil war control variables. ${ }^{35}$ Further, we employ country fixed effects to directly model the influence of time invariant factors correlated with coastal land, such as distance from advanced market economies, that may also influence democratic transition.

There are two endogenous variables, Remit and Remit $\times$ Party. Therefore we add the interaction between $W$ RemitDistance and Party to the excluded instrument set. To mimic the empirical approach used earlier, we employ a linear probability model with country fixedeffects to account for unit-heterogeneity. This allows us to easily estimate the model with two

\footnotetext{
${ }^{33}$ The Appendix includes a model with year fixed-effects, with similar results.

${ }^{34}$ Data on these variables is from Nunn and Puga (2012). See Appendix B for further information on the instrument construction.

${ }^{35}$ In Appendix Table B-2 we show the results remain when controlling for trade level.
} 
endogenous variables and unit effects. ${ }^{36}$ The specification includes the following control variables: Party regime, GDP per capita, Population, Civil war, Neighbor democratization, Net Migration, calendar time period dummies for each 5-year period, and duration time, as well as country fixed effects.

$* * *$ Table 2 about here $* * *$

The first column of Table 2 reports the first stage regression. W RemitDistance is positive and statistically significant, indicating a strong correlation between the excluded instrument and the endogenous variable (F-statistic $>10) .{ }^{37}$ The next column estimates the model without the interaction term; Remit is positive and statistically different from zero. The final column estimates the model with two endogenous variables; and the estimate for Remit $\times$ Party is positive and statistically different from zero. Further, the F-statistic is still larger than 10 with two endogenous variables, and the linear combination of $\beta_{\text {Remit }}+\beta_{\text {Remit } \times \text { Party }}$ is positive and different from zero.

To test the robustness of this finding, the Appendix (Table B-2) reports models: (1) without control variables; (2) without net migration; (3) with trade added; (4) with economic growth added; (5) with growth and protest added; (6) with growth, aid, oil, and capital account openness added; (7) with year fixed-effects; and (8) dropping first stage outliers. The main finding remains in each of these tests. This evidence is consistent with the expectation that remittances increase the chances of democratic transition in dominant party regimes.

\section{Mechanisms}

Our theoretical expectations focus on how remittances influence the prospects of democratic transition by reducing electoral support for incumbent regimes. To this point, we have shown that remittances are associated with a higher likelihood of democratic transition in partybased autocracies. To further explore the proposed causal mechanism, we first look directly at the electoral connection by examining whether remittances are associated with less electoral support for incumbent parties. This test focuses on executive elections in autocracies to establish a direct link between remittances, elections, and democratic transitions. Second, we test whether remittances are also associated with transitions from one autocratic regime to

\footnotetext{
${ }^{36}$ An instrumental variables probit does not converge with two endogenous variables.

${ }^{37}$ We report the Kleibergen Paap rank Wald F statistic.
} 
another, what we call autocratic transitions. The Iranian Revolution of 1979, the ouster of the Mobutu regime in the former Zaire in 1997 by rebel insurgents, and the military coup by a junior officer in Guinea in 2008 are examples of these autocratic transitions. This test helps establish whether remittances are simply a tool to help opponents oust autocratic regimes by any means or whether remittances mostly harm autocracies by furthering the prospects of democratic transition.

\section{The electoral connection}

Remittances, we argue, facilitate democratization in party-based regimes because these dictatorships are the most likely to rely on broad and deep clientelistic networks to buy loyalty. Control of state resources allows the party to reward loyalty through clientelism and targeted public goods.

Case study research on party regimes shows how they use clientelism to mobilize voters while punishing opposition supporters (Magaloni 2006; Greene 2007; Pepinsky 2007). Poor citizens are generally more likely to sell their votes to political patrons since they place a higher value on consumption goods and their votes are relatively cheap compared with higher income voters (Dixit and Londegran 1996). As Magaloni and Kricheli (2010, 128) note, "this punishment regime is particularly effective at trapping poor voters into supporting the dictatorship because their livelihood depends on state transfers." Because they rely on government transfers for consumption, citizens may vote for incumbents despite their true political preferences. For instance, Blaydes (2011) finds that voters in Egypt's 2005 election were often induced by material rewards; and Chhibber (1996) notes that the National Liberation Front (FLN) dominated Algerian politics for three decades by building a large coalition of supporters with oil-funded goods.

Remittances can break clientelist ties by providing extra income to households. Because enjoying the regime's spoils depends on showing electoral support for the incumbent, increasing remittances should influence the likelihood of democratization by changing electoral behavior. ${ }^{38}$ In particular, recipients in party dictatorships should be less likely to vote for incumbent parties as this extra income increases. Citizens may vote for opposition parties or simply abstain from voting, thereby reducing turnout for the ruling party. Indeed, Pfutze (2012) shows that remittances reduced turnout for the PRI in the 2000-

\footnotetext{
${ }^{38}$ Remittances may also influence stability via anti-regime protest. Appendix D provides some evidence that remittances are associated with a higher incidence of protest in party regimes.
} 
2002 elections. In Senegal, Galvan (2001, 60) notes that "the 2000 elections sealed the collapse of the highways-for-ndigel patronage ties between the Socialists and the marabouts." 39

Even though autocratic rulers use elections strategically to prolong their rule (Magaloni 2006; Gandhi and Lust-Okar 2009), elections may lead to liberalizing outcomes (Howard and Roessler 2006; Donno 2013). Indeed, elections have been the most common way through which party regimes have democratized since 1946 and especially since the end of the Cold War. Following our argument above, we expect remittances are associated with lower vote shares for the incumbent regime, which may translate into an electoral loss and a higher likelihood of democratic transition.

\section{*** Table 3 about here ***}

To test this proposition, we examine remittances and changes in incumbent vote share, collecting data on incumbent vote shares for each election and the prior election. ${ }^{40}$ The main dependent variable is the change in vote share for the incumbent in a direct executive election; the measure of remittances is the lagged three-year moving average. ${ }^{41}$ The base specification includes a control variable for lagged economic growth because growth and remittances are correlated; and domestic growth can influence incumbent vote share. The specification accounts for ceiling (and floor) effects by including the incumbent vote share in the prior election as a control variable. The estimator is a generalized linear model with a logit link function that accounts for the bounded nature of the dependent variable. We cluster standard errors by country. Even-numbered columns include the interaction between Remit and Party.

The results in Table 3 indicate a strong negative correlation between remittances and changes in incumbent vote share. The first column reports the base model, with no interaction; the estimate for Remit is negative and statistically different from zero suggesting that as remittances increase, the incumbent vote share declines. The second column reports

\footnotetext{
${ }^{39}$ Marabouts are Murid religious leaders while ndigels are edicts of these leaders that were also used to instruct Murids to vote for the regime party (Galvan 2001). This electoral defeat was largely brought about by the growing financial autonomy of Murids caused by remittances (Dahou and Foucher 2009; Diedhiou 2011). The Murids had traditionally supported the hegemonic Socialist Party. However, since the 1990s "the marabouts adopted a stance of political neutrality, neither supporting the ruling party nor mobilizing support for opposition candidates" (Galvan 2001, 59).

${ }^{40}$ See Appendix $\mathrm{C}$ for information on the coding rules, sources, and data.

${ }^{41}$ See Table C-2 for results from a full error-correction specification.
} 
the interaction specification: the negative relationship between remittances and vote shares is concentrated among party-based regimes. Figure 3 depicts the substantive finding; an increase in remittances from the $25^{\text {th }}$ to the $75^{\text {th }}$ percentile is associated with a decline of roughly 14 percent in the incumbent vote share in party regimes. In other regimes, the remittance effect is negligible.

Additional columns report robustness tests. Columns 3 and 4 report results from models with additional control variables: migration, government spending, civil war, regime duration, and a calendar time trend. ${ }^{42}$ Adding these variables does not materially change the main finding. The next two columns include region- and year-fixed effects, while the final two columns model country fixed effects and drop the lagged dependent variable. This last specification is a difficult test for the theory because the average number of elections per country in the sample is roughly three (see Table C-1). Thus the coefficient estimate for remittances can be interpreted as the marginal effect of a change in the deviation from the insample country-mean level of remittances. Further robustness tests in the Appendix indicate that the result remains in a full error-correction model, when excluding potential outliers, and estimating a robust regression model. ${ }^{43}$

\section{*** Figure 3 about here***}

Figure 3: Remittances and incumbent electoral support. Estimates from column 2, Table 3.

Remittances, elections, and democratic transitions. In the Appendix we provide further evidence linking remittances to democratic transitions via elections. We return to the democratic transition model (equation 1) to examine whether the observed remittance effect occurs in election years or non-election years. First, we test specifications that include a binary indicator for executive Election years. ${ }^{44}$ We then interact Election with remittances, as well as with party regimes and the interaction between party regimes and remittances. We stress that this strategy is not a good one for assessing how elections influence democratic transitions because the information used to code Election is the exact same political event as the information used to code democratic transition (i.e. the election event when the incumbent loses). Thus, the exact same event is included on both sides of the model, making

\footnotetext{
${ }^{42}$ Government spending is lagged one year, with data obtained from World Bank (2010).

${ }^{43}$ See Table C-2.

${ }^{44}$ Results reported in Table A-7. The election variable indicates whether the final round of an election in which the seat of the incumbent is contested took place in an observation country-year. Data are from Hyde and Marinov (2012).
} 
interpretation of Election nonsensical. However, this can be a useful exercise to examine whether the cases in which there is the expected correlation between remittances and democratic transition (in party regimes) occur in election years or non-election years.

Second, we restrict the sample to election years and then estimate a model to show that remittances are correlated with democratic transitions, but only in party regimes. The estimator is a random effects probit with clustered errors, and controls for the unit means from the full sample. Thus the remittance coefficients can be interpreted as the time-varying deviation from the country mean level of remittances - similar to the interpretation in the main reported results in Table 1.

Both strategies yield findings consistent with our expectations: remittances are only associated with democratic transition in party regimes in election years; and restricting the sample to election years, remittances are only associated with democratic transition in party regimes.

\section{Autocratic transitions}

Next, we examine whether remittances are associated with autocratic regime collapse that results in a transition to a new autocracy: autocratic transitions. The Iranian Revolution of 1979, the ouster of the Mobutu regime in the former Zaire in 1997 by rebel insurgents, and the military coup by a junior officer in Guinea in 2008 are examples of these regime collapse events. We examine the same models as those reported in Tables 1 and 2, but switch the dependent variable from democratic transition to autocratic transition. Appendix Tables A-6 and B-3 report the results. We find no evidence that remittances are associated with autocratic transitions. This should not be surprising because examination of these regime collapse cases shows that only 3 of the 34 autocratic transitions entail any sort of election (the subsequent regime in each of these three cases is not a democracy). ${ }^{45}$ The other 31 regime collapse events are popular revolutions, military coups, and insurgents or rebels toppling the regime. In contrast, 31 of 49 democratic transition events entail elections. This provides additional support to the claim that remittances influence autocratic regime survival by increasing the prospect of democratic transition.

\footnotetext{
${ }^{45}$ Table S-3 in the Appendix lists each collapse event in the sample period; whether it is coded as a democratic or autocratic transition; and whether the event is an election.
} 
$* * *$ Figure 4 about here $* * *$

Figure 4: Remittances and regime transitions. The left panel depicts the marginal effect of remittances on the likelihood of democratic transition, using the observed values approach. The marginal effect simulation reflects an increase in remittances from the 25th to the 75th percentile. The right panel depicts the marginal effect on the likelihood of autocratic transition.

Figure 4 contrasts the substantive finding from the democratic and autocratic transition models. The left panel depicts the substantive finding for the democratic transition model reported in column 4, Table 1, using the observed values approach suggested by Hanmer and Kalkan (2013). The estimates correspond to an increase in remittances from the 25 th percentile of the remittance distribution to the 75 th percentile. In party regimes, this change in remittances is associated with a 12 percent increase in the predicted probability of democratic transition, while in other regimes a similar change in remittances results in a negligible change in the predicted risk of transition. The right panel shows the substantive finding from the same model but with autocratic transition as the dependent variable (column 4, Table A-6). There is no relationship between remittances and these types of regime collapse events.

\section{Discussion and Conclusion}

This article contributes to our understanding of the impact of migration and remittances in the politics of sending countries, adding to the expanding literature on how international migration shapes domestic politics. The evidence in this paper suggests that remittances do not stabilize autocracies, or at least not all of them. Rather, we show that remittance flows jeopardize autocratic rule by increasing the prospects of a democratic transition. Using data over a 35-year period covering the third wave of democratization, we find that remittances are associated with a higher likelihood of democratic transition in party dictatorships and a lower vote share for incumbent parties in autocratic elections.

Together, these findings stand at odds with recent research which suggests that remittances stabilize autocracies (Ahmed 2012). Three possibilities may account for these divergent findings. First, we look at remittances separately from other types of non-tax revenue, such as foreign aid. Our measure of this concept does not conflate changes in worker remittances with changes in the receiving country's economy, which are also likely to 
influence autocratic stability. Second, we focus on democratic transitions instead of all government changes in autocracies. The events we model, therefore, do not include institutionalized rotation of leaders atop an autocratic regime or the natural death of a leaderunless these also entail the regime being ousted from power. Finally, our account of how remittances influence autocratic stability emphasizes an electoral connection (Pfutze 2012). Some dictatorships rely on retaining the support of a broad-based electoral coalition and employ a range of state resources to secure their continued support. This is a qualitative characteristic of autocracy measured with a binary indicator for party-based regimes.

We argue that remittances can change the electoral behavior of voters in regimes with a broad-based electoral connection to their supporters, namely party dictatorships. If remittances reduce electoral support for incumbents in these regimes, they should also increase the prospects of democratization. We find evidence consistent with this proposition: remittances are associated with a higher likelihood of democratic transition in party regimes. In other dictatorships, however, remittances appear to have little influence on transitions. We then investigate how remittances change incumbent vote shares in autocratic elections, and find that higher remittance flows are associated with a decline in electoral support for incumbent parties, but again only in dominant party autocracies. ${ }^{46}$

Our explanation for how remittances influence autocratic stability does not rule out the possibility that they allow dictatorships to reduce public goods spending in favor of particularistic spending on core elites. Indeed, this may be one reason why remittances do not appear to influence the prospects of democratization in a range of non-party based dictatorships, including personalist autocracies. ${ }^{47}$ However, central to understanding the spending substitution effect is the task of identifying the core regime elite in different autocratic contexts as well as the marginal influence of increased private spending on their loyalty to the dictator.

Our findings not only have implications for research on the consequences of international flows for domestic democratic development but also inform important policy questions. Because dominant party autocracies have been some of the most resilient dictatorships in the past six decades, our findings suggest that migration policies which enhance the flow of remittances to sending autocratic countries may be an increasingly influential tool of foreign policy for wealthy democracies interested in promoting democracy

\footnotetext{
${ }^{46}$ Moreover, the alternative hypothesis that remittances facilitate regime durability by easing dissatisfaction with incumbents does not find support in dominant party regimes.

47 Table A-5 shows remittances are not associated with an increased likelihood of democratic transition in personalist autocracies.
} 
abroad. However, because remittances are most likely to further democratization by eroding electoral support for incumbent autocratic parties, they may contribute little to the political change in regimes such as China's that do not hold multiparty elections at the national level. 


\section{References}

Abdih, Yasser, Ralph Chami, Jihad Dagher and Peter Montiel. 2012. "Remittances and Institutions: Are Remittances a Curse? " World Development 40(4): 657-666.

Adams, Richard H. and John Page. 2005. "Do International Migration and Remittances Reduce Poverty in Developing Countries?" World Development 33(10): 1645-1669.

Adida, Claire L. and Desha M. Girod. 2011. "Do Migrants Improve Their Hometowns? Remittances and Access to Public Services in Mexico, 1995-2000." Comparative Political Studies 44(1): 3-27.

Ahmed, Faisal Z. 2011. “Remittances, Clientelism, and Electoral Dynamics.” Working Paper.

Ahmed, Faisal Z. 2012. "The Perils of Unearned Foreign Income: Aid, Remittances, and Government Survival." American Political Science Review 106(1): 146-165.

Arriola, Leonardo R. 2008. "Ethnicity, Economic Conditions, and Opposition Support: Evidence from Ethiopia's 2005 Elections." Northeast African Studies 10(1): 115-144.

Bearce, David H and Jennifer A. Laks Hutnick. 2011. "Toward an alternative explanation for the resource curse: Natural resources, immigration, and democratization." Comparative Political Studies 44(6): 689-718.

Beck, Nathaniel, Jonathan N. Katz and Richard Tucker. 1998. "Taking time seriously: Time-seriescross-section analysis with a binary dependent variable." American Journal of Political Science 42(4): 1260-1288.

Bermeo, Sarah B. 2011. "Foreign Aid and Regime Change: A Role for Donor Intent." World Development 39(11): 2021-2031.

Blaydes, Lisa. 2011. Elections and Distributive Politics in Mubarak's Egypt. New York: Cambridge University Press.

Bratton, Michael and Nicolas van de Walle. 1994. "Neopatrimonial Regimes and Political Transitions in Africa." World Politics 46(4): 453-489.

Bueno de Mesquita, Bruce and Alastair Smith. 2010. "Leader Survival, Revolutions, and the Nature of Government Finance.” American Journal of Political Science 54(4): 936-950.

Bueno de Mesquita, Bruce, Alastair Smith, Randolph Siverson and James Morrow. 2003. Logic of Political Survival. Cambridge: MIT Press.

Burgess, Katrina. 2014. "Unpacking the Diaspora Channel in New Democracies: When Do Migrants Act Politically Back Home?" Studies in Comparative International Development 49(1): 13-43.

Careja, Romana and Patrick Emmenegger. 2012. "Making Democratic Citizens: The Effects of Migration Experience on Political Attitudes in Central and Eastern Europe." Comparative Political Studies 45(7): 875-902.

Carter, David and Curt Signorino. 2010. "Back to the Future: Modeling Time Dependence in Binary Data." Political Analysis 18(3): 271-292. 
Chami, Ralph, Adolfo Barajas, Thomas Cosimano, Connel Fullenkamp, Michael Gapen and Peter Montial. 2008. The Macroeconomic Consequences of Remittances. Washington, DC: International Monetary Fund, Occasional Paper 259.

Chaudhry, Kiren A. 1989. "The Price of Wealth: Business and State in Labor Remittance and Oil Economies.” International Organization 43(1): 101-145.

Cheibub, José Antonio, Jennifer Gandhi and James Raymond Vreeland. 2010. "Democracy and Dictatorship Revisited." Public Choice 143(1-2): 67-101.

Chhibber, Pradeep. 1996. "State Policy, Rent Seeking, and the Electoral Success of a Religious Party in Algeria." The Journal of Politics 58(1): 126-148.

Chinn, Menzie D. and Hiro Ito. 2008. "A New Measure of Financial Openness." Journal of Comparative Policy Analysis 10(3): 309-322.

Collier, Paul. 2013. Exodus: How Migration is Changing Our World. Oxford University Press.

Collier, Paul and Anke Hoeffler. 2004. "Greed and Grievance in Civil War." Oxford Economic Papers 56(4): 563-595.

Dahou, Tarik and Vincent Foucher. 2009. Senegal since 2000: Rebuilding Hegemony in a Global Age. In Turning Points in African Democracy, ed. Abdul Raufu Mustapha Lindsay Whitfield. Cambridge: Boydell \& Brewer. pp. 13-30.

Dancygier, Rafaela M. 2010. Immigration and Conflict in Europe. Cambridge University Press.

Davenport, Christian. 2007. "State Repression and the Tyrannical Peace." Journal of Peace Research 44(4): 485-504.

Desai, Raj M., Anders Olofsgard and Tarik M. Yousef. 2009. "The Logic of Authoritarian Bargains." Economics and Politics 21(1): 93-125.

Diaz-Cayeros, Alberto, Beatriz Magaloni and Barry R. Weingast. 2003. "Tragic Brilliance: Equilibrium Hegemony and Democratization in Mexico." Working paper, Stanford University.

Diedhiou, Alpha. 2011. "Remittances, Transnational Dahiras and Governance in Senegal." International Migration. Published online.

Dionne, Kim Yi, Kris L. Inman and Gabriella R. Montinola. 2014. "Another Resource Curse? The Impact of Remittances on Political Participation.” Afrobarometer Working Paper No. 145.

Dixit, Avinash and John B. Londegran. 1996. "The Determinants of Success of Special Interests in Redistributive Politics.” Journal of Politics 58(4): 1132-1155.

Djankov, Simeon, Jose G. Montalvo and Marta Reynal-Querol. 2008. "The Curse of Aid.” Journal of Economic Growth 13(3): 169-194.

Donno, Daniela. 2013. "Elections and Democratization in Authoritarian Regimes." American Journal of Political Science 57(3): 703-716.

Dunning, Thad. 2004. "Conditioning the Effects of Aid: Cold War Politics, Donor Credibility, and Democracy in Africa." International Organization 58(2): 409-423. 
Eckstein, Susan. 2010. "Remittances and their Unintended Consequences in Cuba." World Development 38(7): 1047-1055.

Fajnzylber, Pablo J. and Humberto López. 2007. Close to Home: The Development Impact of Remittances in Latin America. Washington, DC: The International Bank for Reconstruction and Development, World Bank.

Freund, Caroline and Nikola Spatafora. 2008. "Remittances, Transaction Costs, and Informality." Journal of Development Economics 86(2): 356-366.

Galvan, Dennis. 2001. "Political Turnover and Social Change in Senegal." Journal of Democracy 12(3): 51-62.

Gandhi, Jennifer. 2008. Political Institutions under Dictatorship. New York: Cambridge University Press.

Gandhi, Jennifer and Ellen Lust-Okar. 2009. "Elections under Authoritarianism." Annual Review of Political Science 12: 403-422.

Geddes, Barbara. 1999. "What Do We Know About Democratization After Twenty Years?" Annual Review of Political Science 2: 115-144.

Geddes, Barbara. 2003. Paradigms and Sand Castles. Ann Arbor: University of Michigan Press.

Geddes, Barbara, Erica Frantz and Joseph Wright. 2014. "Military Rule.” Annual Review of Political Science 17: Forthcoming.

Geddes, Barbara, Joseph Wright and Erica Frantz. 2014. "Autocratic Regimes: A New Data Set." Perspectives on Politics 14: Forthcoming.

Germano, Roy. 2013. "Migrants' Remittances and Economic Voting in the Mexican Countryside." Electoral Studies 32(4): 875-885.

Gleditsch, Nils Petter, Peter Wallensteen, Mikael Eriksson, Margareta Sollenberg and Håvard Strand. 2002. “Armed Conflict 1946-2001: A New Dataset.” Journal of Peace Research 39(5): 615-637.

González, Guadalupe, Jorge A. Schiavon, David Crow and Gerardo Maldonado. 2011. México, Las Américas y el Mundo 2010. Ciudad de México: CIDE.

Goodman, Gary L. and Jonathan Hiskey. 2008. "Exit without Leaving: Political Disengagement in High Migration Municipalities in Mexico." Comparative Politics 40(2): 169-188.

Greene, Kenneth F. 2007. Why Dominant Parties Lose: Mexico's Democratization in Comparative Perspective. New York: Cambridge University Press.

Greene, Kenneth F. 2010. "The Political Economy of Authoritarian Single Party Dominance." Comparative Political Studies 43(9): 1-27.

Haber, Stephen and Victor Menaldo. 2011. "Do Natural Resources Fuel Authoritarianism? A Reappraisal of the Resource Curse.” American Political Science Review 105(1): 1-26.

Hanmer, Michael J. and Kerem Ozan Kalkan. 2013. "Behind the curve: Clarifying the best approach to calculating predicted probabilities and marginal effects from limited dependent variable models." American Journal of Political Science 57(1): 263-277. 
Herb, Michael. 1999. All In the Family: Absolutism, Revolution, and Democracy in the Middle Eastern Monarchies. Albany, NY: State University of New York Press.

Hirschman, Albert O. 1978. "Exit, Voice, and the State." World Politics 31(1): 90-107.

Hiskey, Jonathan, Jorge D. Montalvo and Diana Orcés. 2014. "Democracy, Governance, and Emigration Intentions in Latin America and the Caribbean." Studies in Comparative International Development 49(1): 89-111.

Howard, Marc M. and Philip G. Roessler. 2006. "Liberalizing Electoral Outcomes in Competitive Authoritarian Regimes.” American Journal of Political Science 50(2): 365-381.

Huntington, Samuel P. 2004. “The Hispanic Challenge.” Foreign Policy 141(2): 30-45.

Hyde, Susan D. and Nikolay Marinov. 2012. "Which Elections Can Be Lost?" Political Analysis 20(2): 191-210.

IMF. 2005. World Economic Outlook: Globalization and External Imbalances. Washington, DC: International Monetary Fund.

Iskander, Natasha. 2010. Creative State: Forty years of migration and development policy in Morocco and Mexico. Ithaca, NY: Cornell University Press.

Kapur, Devesh. 2010. Diaspora, Development and Democracy. The Domestic Impact of International Migration from India. New Jersey: Princeton University Press.

Kapur, Devesh and John McHale. 2005. Give Us Your Best and Brightest: The Global Hunt for Talent and its Impact on the Developing World. Center for Global Development.

Kapur, Devesh and John McHale. 2012. "Economic Effects of Emigration on Sending Countries." In Oxford Handbook of the Politics of International Migration, ed. Marc R. Rosenblum and Daniel J. Tichenor. Oxford: Oxford University Press. pp. 131-152.

Kono, Daniel Yuichi and Gabriella R. Montinola. 2009. "Does Foreign Aid Support Autocrats, Democrats, or Both?" Journal of Politics 71(2): 704-718.

Levitsky, Steven and Lucan A. Way. 2010. Competitive Authoritarianism: Hybrid Regimes after the Cold War. Cambridge: Cambridge University Press.

Levitt, Peggy. 1998. "Social Remittances: Migration Driven Local-Level Forms of Cultural Diffusion." International Migration Review 32(4): 926-948.

Lyons, Terrence. 2007. "Conflict-Generated Diasporas and Transnational Politics in Ethiopia." Conflict, Security and Development 7(4): 529-549.

Magaloni, Beatriz. 2006. Voting for Autocracy: Hegemonic Party Survival and its Demise in Mexico. Cambridge: Cambridge University Press.

Magaloni, Beatriz and Ruth Kricheli. 2010. "Political Order and One-Party Rule." Annual Review of Political Science 13: 123-143.

Malesky, Edmund, Regina Abrami and Yu Zheng. 2011. "Institutions and Inequality in Single-Party Regimes: A Comparative Analysis of Vietnam and China." Comparative Politics 43(4): 409-427. 
McMann, Kelly M. 2006. Economic Autonomy and Democracy: Hybrid Regimes in Russia and Kyrgyzstan. Cambridge: Cambridge University Press.

Menaldo, Victor. 2012. "The Middle East and North Africa's Resilient Monarchs." Journal of Politics 74(3): 707-722.

Meseguer, Covadonga and Katrina Burgess. 2014. "International Migration and Home Country Politics." Studies in Comparative International Development 49(1): 1-12.

Messina, Anthony M. 2007. The Logics and Politics of post-WWII Migration to Western Europe. Cambridge Univ Press.

Miller, Gina Lei and Emily Hencken Ritter. 2014. "Emigrants and the Onset of Civil War." Journal of Peace Research 51(1): 51-64.

Morrison, Kevin. 2009. "Oil, Non-Tax Revenue, and the Redistributional Foundations of Regime Stability.” International Organization 63(1): 107-138.

Moses, Jonathon W. 2011. Emigration and Political Development. Cambridge University Press.

Nunn, Nathan and Diego Puga. 2012. "Ruggedness: The Blessing of Bad Geography in Africa." Review of Economics and Statistics 94(1): 20-36.

Nyblade, Benjamin and Angela O'Mahony. 2014. "Migrants' Remittances and Home Country Elections: Cross-National and Subnational Evidence." Studies in Comparative International Development 49(1): 44-66.

O’Mahony, Angela. 2013. "Political Investment: Remittances and Elections." British Journal of Political Science 43(4): 799-820.

Omgba, Luc D. 2009. "On the Duration of Political Power in Africa: The Role of Oil Rents." Comparative Political Studies 42(3): 416-436.

Orozco, Manuel, Elisabeth Burgess and Corinne Massardier. 2010. "Remittance Transfers in Senegal: Preliminary Findings, Lessons, and Recommendations on its Marketplace and Financial Access Opportunities.” ILO, International Migration Paper No. 109.

Orrenius, Pia M. and Madeline Zavodny. 2012. "Economic Effects of Migration: Receiving States." In Oxford Handbook of the Politics of International Migration, ed. Marc R. Rosenblum and Daniel J. Tichenor. Oxford: Oxford University Press. pp. 105-130.

Pepinsky, Thomas B. 2007. "Autocracy, Elections, and Fiscal Policy in Malaysia." Studies in Comparative International Development 42(1-2): 136-163.

Pérez-Armendáriz, Clarisa. 2014. "Cross-Border Discussions and Political Behavior in MigrantSending Countries.” Studies in Comparative International Development 49(1): 67-88.

Pérez-Armendáriz, Clarisa and David Crow. 2010. "Do Migrants Remit Democracy? International Migration, Political Beliefs, and Behavior in Mexico." Comparative Political Studies 43(1): 119148.

Pfutze, Tobias. 2012. "Does Migration Promote Democratization? Evidence from the Mexican Transition." Journal of Comparative Economics 40(2): 159-175. 
Pfutze, Tobias. 2013. "Clientelism vs. Social Learning: The Electoral Effects of International Migration." International Studies Quarterly. Published online.

Ratha, Dilip, Sanket Mohapatra, Çaglar Özden, Sonia Plaza, William Shaw and Abebe Shimeles. 2011. Leveraging migration for Africa. Remittances, Skills and Investments. Washington, DC: World Bank.

Regan, Patrick M. and Richard W. Frank. 2014. "Migrant Remittances and the Onset of Civil War." Conflict Management and Peace Science. Published online.

Ross, Michael. 2001. “Does Oil Hinder Democracy?” World Politics 53(3): 325-361.

Ross, Michael. 2008. “Oil, Islam, and Women.” American Political Science Review 102(1): 107-123.

Smith, Alastair. 2008. “The Perils of Unearned Income.” Journal of Politics 70(3): 780-793.

Smith, Benjamin. 2004. "Oil Wealth and Regime Survival in the Developing World: 1960-1999." American Journal of Political Science 48(2): 232-246.

Smith, Benjamin. 2005. "Life of the Party: The Origins of Regime Breakdown and Persistence under Single-Party Rule.” World Politics 57(3): 421-451.

Tyburski, Michael D. 2012. "The Resource Curse Reversed? Remittances and Corruption in Mexico." International Studies Quarterly 56(2): 339-350.

Ulfelder, Jay. 2005. "Contentious Collective Action and the Breakdown of Authoritarian Regimes." International Political Science Review 26(3): 311-334.

Ulfelder, Jay. 2007. "Natural-Resource Wealth and the Survival of Autocracy." Comparative Political Studies 40(8): 995-1018.

Wooldridge, Jeffrey M. 2002. Econometric Analysis of Cross Section and Panel Data. Cambridge MA: MIT Press.

World Bank. 2006a. The Development Impact of Workers' Remittances in Latin America: Main Findings (vol. 1 \& 2). Washington, DC: World Bank.

World Bank. 2006b. Global Economic Prospects: Economic Implications of Remittances and Migration. Washington, DC: World Bank.

World Bank. 2010. World Development Indicators 2010. Washington, DC: World Bank.

World Bank. 2011. Migration and Remittances Factbook [2nd Edition]. Washington, DC: World Bank.

Wright, Joseph. 2009. "How Foreign Aid Can Foster Democratization in Authoritarian Regimes." American Journal of Political Science 53(3): 552-571.

Wright, Joseph, Erica Frantz and Barbara Geddes. 2014. "Oil and Autocratic Regime Survival." British Journal of Political Science 44: Forthcoming. 